\title{
Tarihi Beyşehir Eşrefoğlu Camisi Bazı Ahşap Sütunlarında Tür Teşhisi
}

\author{
Bilgin İÇEL ${ }^{1 *}$ \\ ${ }^{1}$ Çanakkale Onsekiz Mart Üniversitesi, Terzioğlu Kampüsü17020, ÇANAKKALE
}

\section{Öz}

ICOMOS (Uluslararası Anıtlar ve Sitler Konseyi), tarihi varlıklara ait ahşap parçaları değiştirmek için aynı ağaç türlerinin kullanılması gerektiği ilkesini belirlemiştir. 2011 yılından bu yana UNESCO Dünya Mirası Geçici Listesinde yer alan Eşrefoğlu Camisi, mimari özellikleri ve malzemeleri ile büyük önem taşımaktadır. Bu çalışmada, 700 yılı aşkın süredir kullanımda olan bazı yapısal taşıyıcı sütunların ağaç türleri belirlenmiştir. Enine, radyal ve teğet kesitlerde anatomik özellikler incelenmiştir. Tür tanımlaması için, bir türe özgün olan bazı anatomik özellikler teşhis aşamasında uzmanlara büyük kolaylık sağlamaktadır. Mikroskobik kesitlerde yapılan tüm incelemelere bağlı olarak, özellikle dişli torus yapısı, incelenen ahşap örneklerinin Gymnospermae'lerden Pinaceae familyası, sedir (Cedrus) cinsine ait olduğunu göstermiştir. Bu çalışmada ilgili zamandaki tedarik ve taşıma imkanları, yakın orman alanlarındaki Toros sediri doğal yayılışı göz önünde bulundurularak, incelenen malzemenin ağaç türünün Cedrus libani A. Rich. (Toros sediri) olduğu kanaatine varılmıştır. Bu sonucun camide sadece araştırılan sütunlar için geçerli olduğunu vurgulamak önem arz etmektedir.

Anahtar Kelimeler: Eşrefoğlu Camisi, Toros sediri, odun anatomisi, tür teşhisi.

\section{Identification of Wood species for some of Column Members of Historic Beyşehir Eşrefoğlu Mosque}

\begin{abstract}
ICOMOS (International Council on Monuments and Sites), charted a principle that the same wood species should be used for substituting old members of historic assets. Eşrefoğlu mosque which is placed in UNESCO World Heritage Temporary List since 2011, has a great importance with its architectural properties and materials. In this study, some structural column members of over 700 years age of use, were investigated to identify their wood species. Anatomical features in transverse, radial and tangential sections were investigated. For species identification, some of anatomical characteristics that are unique of a species is very helpful for wood experts. Depending on all observations from sections, particularly scalloped tori shown that the investigated wood samples were belonged to the genus Cedar (Cedrus). The samples were identified as Cedrus libani A. Rich. (Taurus cedar) considering the supply and transportation possibilities at the relevant time and the stand type in the nearby forest lands. However, it is very important to emphasize that the results are valid only for the anatomically investigated columns not for the others in the mosque.
\end{abstract}

Keywords: Eşrefoğlu mosque, Taurus cedar, wood anatomy, wood identification 


\section{Giriş}

Anadolu Selçukluları döneminde özellikle Orta Anadolu ile İç Batı Anadolu'da yaygın olarak görülen ahşap sütunlu ve tavanlı cami mimarisi geleneği, Selçukluların ardından beylikler döneminde de devam etmiştir. Bu dönemde Ankara, Konya, Beyşehir, Kastamonu, Niğde ve Afyon çevreleri başta olmak üzere Anadolu'nun birçok yöresinde ahşap direkli ve tavanlı ibadet yapılarıyla karşılaşılmaktadır (Erakan, 2010; Uysal, 2014). Beyşehir'de Beylikler dönemine ait Anadolu'nun ahşap direkli en önemli camilerinden biri olarak kabul edilen Eşrefoğlu Camisi (Şekil 1), ana taşıyıcı sütunların ahşap olması ve iç kısmındaki donatılarda yaygın olarak ahşap malzemenin kullanılmış olması ve süslemeleri sebebiyle birçok açıdan önem atfedilen bir yapı olarak dikkat çekmektedir (Önge, 1975; Koçu, 2014). Eşrefoğlu Camisi 2011 yılından itibaren UNESCO Dünya Mirası Geçici Listesi'ndeki alanlar içerisinde yer almaktadır (URL1).
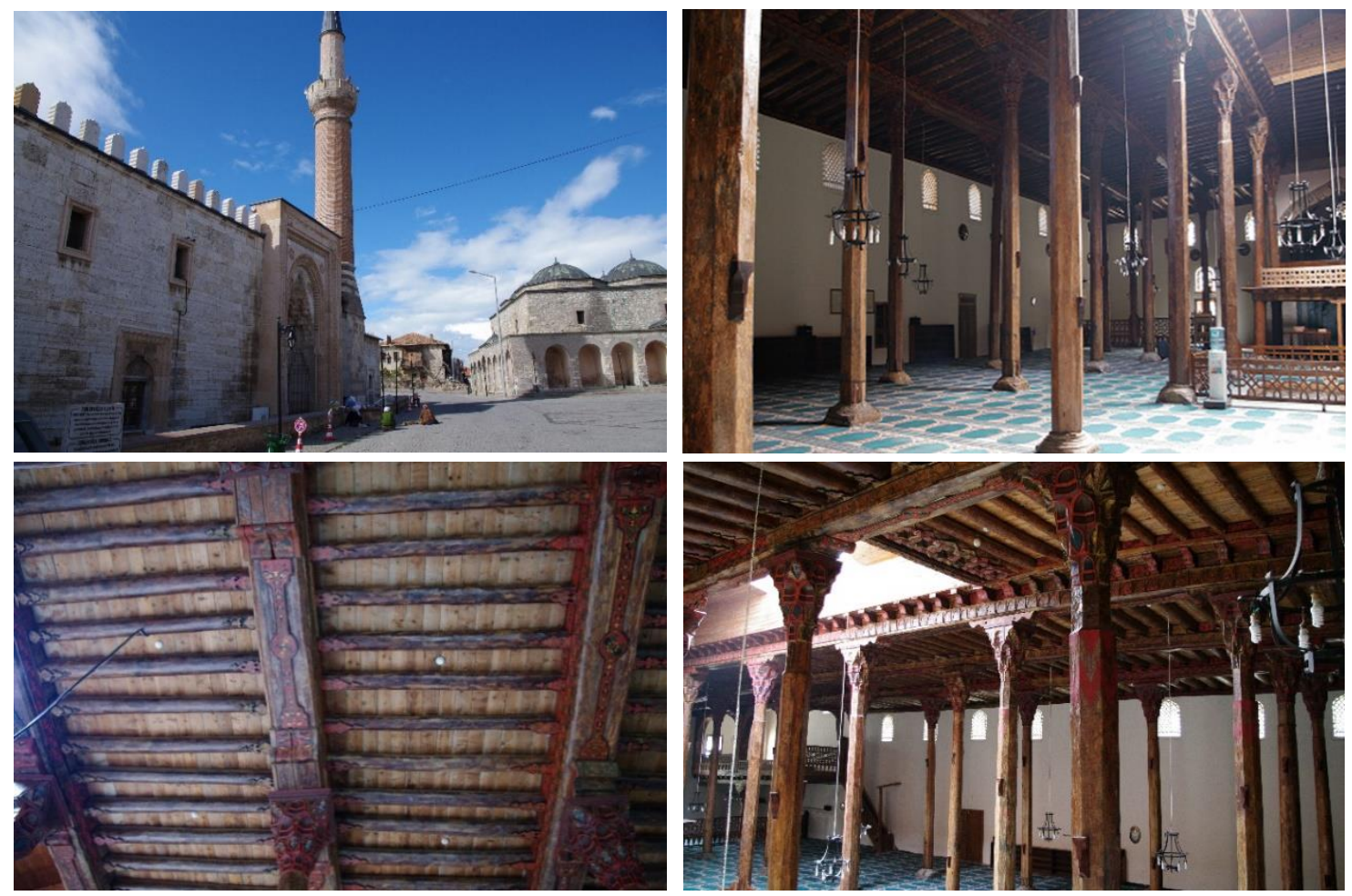

Şekil 1. Eşrefoğlu Camisi dış ve iç görüntüsüne ait fotoğraflar (Foto: Bilgin İÇEL)

Yapının, Eşrefoğulları Beyliği’nin kurucusu Seyfeddin Süleyman Bey tarafindan yaptırıldığı belirtilmektedir. Taçkapı üzerinde yer alan kitabe şeklindeki vakfiyesinden bir han ve çifte hamamla birlikte inşa edilmiş olduğu öğrenilmektedir. Ahşap direkli ve başlangıçta düz toprak damlı olarak inşa edilmiş, (çatı sonradan değiştirilmiştir) (Efe, 2012; Koçu, 2014) camilerin en önemli örneği olarak gösterilmektedir. Caminin yapılış tarihi ile ilgili bilgi, camideki kitabelerde belirtilmektedir. Bu kitabelerin desteklediği bilgi caminin 1296-1299 (Miladi) y1lları arasında Seyfettin Süleyman Bey tarafindan yaptırıldığıdır (buradan binanın en az üç yılda tamamlandığı anlaşılmaktadır (Efe,2012; URL2). Bu kitabeler ve yapı hakkında yapılmış diğer çalışmalarda geçen bilgiler (örneğin; Çetinaslan (2013) te yapım yılı 1297-99; Koçu (2014) te 1296-99 olarak verilmektedir) esas alındığında caminin inşasından bu yana 700 yıldan fazla bir zaman geçtiği anlaşılmaktadır. Bu kadar uzun bir süre geçmesine rağmen halen ayakta ve görevini yapan ahşap sütunların hangi ağaç türüne ait olduğunun bilimsel kanıtlara dayalı olarak bilinmesi önemlidir. Tarihi ahşap yapıların restorasyonu ile ilgili yayınlarda, yapıda kullanılan malzemelerin incelenip türlerinin tespit edilmesi ve yapılan/yapılacak restorasyonda aynı ağaç türlerinin kullanılmasına dikkat edilmesi, orijinale sadık kalmak ilkesine uyulması gibi konulara dikkat çekilmektedir (Yeğin, 2008; Croatto ve Turrini, 2014; Brancaccio, 2016; Zvyagintseva, 2017). Ağaç türünün bilinmesinin önemine başka çalışmalarda da dikkat çekilmektedir (Timar vd., 2012; Macchioni ve Bernabei, 2018). 1965 yılında kurulan ICOMOS (International Council on Monuments and Sites) tarihi ahşap yapılarda restorasyon işlemlerinde aynı ağaç türünün kullanılması prensibini benimsemiştir (Doh, 2000). Bu açıdan tarihi yapıda kullanılan ahşap elemanların hangi ağaç türüne ait olduğunun tespit edilmesi yani tür teşhisinin doğru yapılması önemlidir.

Son yıllarda söz konusu yapıdaki sütunların tamamının sedir olduğuna dair anlaşılmalara sebep olan/olabilecek 
birtakım bilgilere ve haberlere bazı kaynaklarda rastlanılmıştır (Örn: Akkanat, 2009-sayfa 56; Efe, 2012 sf.73; Çavuş, 2018-sayfa 26; URL3). Söylence şeklinde nesilden nesile aktarılan, yöredeki yaşlı bireylerle konuşulduğunda halen dile getirilen ve direklerin sedir ağacından olduğuna dair sözlü bilgiler yanında, değişik sebepler bu genellemenin yapılmasına vesile olmuş olabilir. Eşrefoğlu Camisi ahşap kısımları ile ilgili bilimsel anatomik bir incelemeyi içeren ilk çalışmalar; 2010 yılında gelen resmi bir talep yazısı sonrasında yazar tarafından gerçekleştirilmiş bir çalışma ve devamında 2015 yılında camide bazı sütunlarda yapılmış anatomik incelemelerdir. Mevcut bilimsel çalışmalar ve bilgiler doğrultusunda tüm ağaçların sedir olarak teşhis edilmiş olduğuna dair bir veri olmamasına rağmen, bu hususta bazı genellemelere rastlanmış olması sonrasında, bu konuya bilimsel açıklık getirilmesine ihtiyaç duyulmuştur. Literatürde ve bazı web sayfalarında rastlanan ve tüm ahşap sütunların sedir olduğuna dair bilgilerin/genellemelerin düzeltilmesi amacıyla bugüne kadar yapılan bilimsel tür teşhisi çalışmaları bu makalede paylaşılmıştır.

\section{Materyal ve Metot}

\subsection{Materyal}

Eşrefoğlu Camisine 2010 ve 2015 yıllarında yapılan inceleme ziyaretlerinden elde edilen örnekler çalışma materyalini oluşturmaktadır. Yapılan ilk ziyarette örnek alımı aşamasında ortaya konulan kısıtlamalar sebebiyle, sütunlardan sadece 21 numaralı sütunda iki farklı kısımda kopmak üzere olan küçük odun parçaları (2 adet) bulunmuştur. Yapı ile ilgili olarak ikinci inceleme 2015 yılında gerçekleştirilmiştir. İkinci örnek alımında altı sütundan $(2,9,12,15,18$ ve 23 numaralı) metot kısmında açıklanan cihaz ile örnek alınmıştır. Böylelikle iki farklı yılda ve toplamda 7 adet sütundan alınan örnekler kullanılarak tür teşhisi yapılmıştır. Bu çalışmada 700 yıldan fazla bir geçmişi olan koruma altındaki tarihi ahşap sütunların odun türü teşhisinde karşılaşılan en önemli güçlük; örnek alımı hususunda ortaya koyulan kısıtlar sebebiyle ancak çok küçük boyuttaki örneklerin alınabilmiş olmasıdır. Cami içerisinde Kadınlar mahfili kısmında 5, ana ibadet kısmında 42 adet ahşap sütun bulunmaktadır. Kadınlar mahfilindeki sütunlar çalışmanın ilk planlama aşamasında bazı gerekçeler ile kapsam dışında tutulduğu ve numaralanmadığı için, burada bilgi olarak verilmiş fakat krokide gösterilmemiştir. Bu bilgiye burada değinilmesinin sebebi; ileride bu makalenin kaynak alınması durumunda camideki sütun sayıları açısından doğru bilginin verilmesi amacıyladır. Genel olarak cami ile ilgili kayıtlarda ana ibadet kısmı ve kadınlar mahfili kısmı ayrı belirtildiği için bu krokide de buna uyulmuştur (Şekil1).

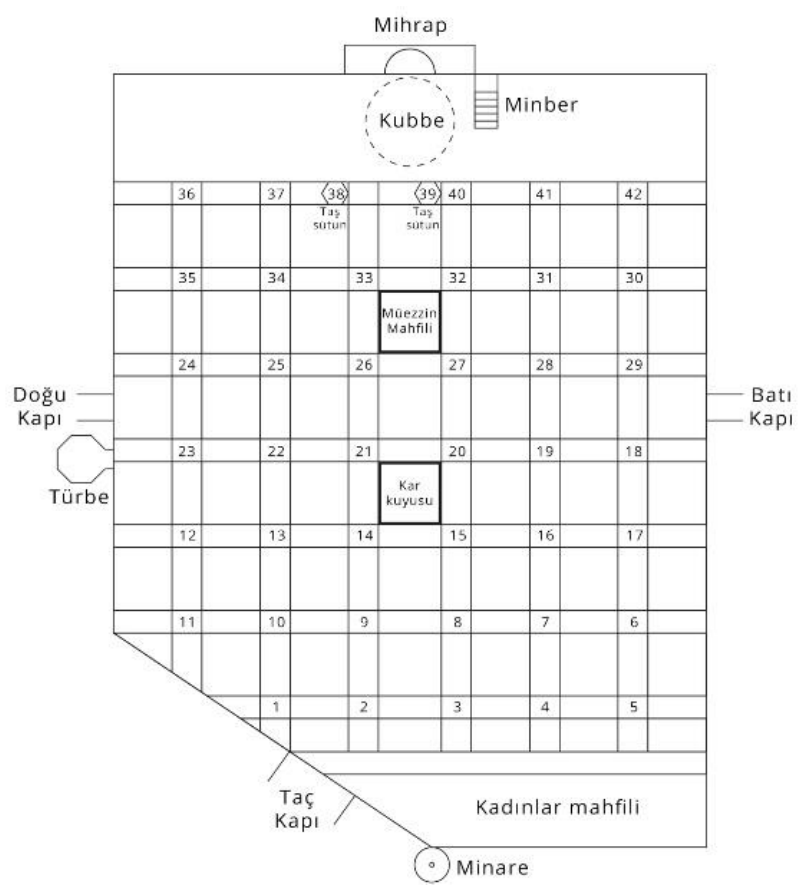

Şekil1. Ahşap sütunların yerlerini tanımlamak için yapılan numaralandırma ve çizilen kroki. Çizim ölçeksiz yapılmış olup, yalnızca ana ibadet kısmındaki ahşap sütunların belirlenmesi için yazar tarafından yapılan numaralandırmayı içermektedir. (Kadınlar mahfilindeki sütunlar krokide gösterilmemiştir) 


\subsection{Metot}

Odun teşhisinde kullanılan farklı yöntemlerin tanıtıldığı bir makalede; emprenye edilmiş, boyanmış ya da cilalanmış örneklerde ayrıca çürümüş haldeki odun örneklerinden kesit alma ve preparasyon işlemlerinin güç olduğu belirtilmektedir (Doğu, 2001). Çalışmada genel kaideler itibariyle UNI 11118 dikkate alınmıştır. Preparat hazırlama işleminden önce literatürdeki benzer çalışmalar incelenmiştir. Özellikle Kore'de yapılmış, konu ve içerik olarak bu çalışmaya benzer bir çalışmanın metodolojisi incelenmiştir (Hwanng vd., 2009). İncelenen bu makalede

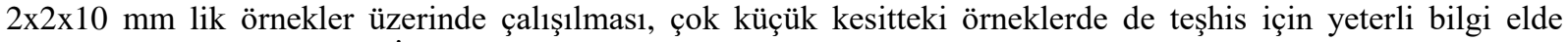
edilebildiğini göstermiştir. İlgili yayında odun örneklerinin \%50 lik alkolde bekletildikten sonra kesit alma işleminin yapıldığı belirtilmektedir. İlk ziyarette elde edilen bir parçada aynı işlem basamakları denendikten sonra başarılı bir kesit elde edilememiştir. Bunun sebebi ilgili yayındaki türlerin farklı türler olması ve odun örneklerinin kullanımda olma zamanı olarak bu çalışmadaki örneklerle arasında yaşlanma farkı olması olabilir. Bu nedenle elde bulunan aynı ağaç türüne ait başka eski odun örnekleri ile denemeler yapılmıştır (bu örnekler yazar tarafından değişik vesilelerle Akdeniz Bölgesinde köy-yayla evleri vb. mekanlardan toplanmış olup, kaç yıllık kullanımda olduklarına dair kesin bilgiler bilinmemektedir). Bu denemelerde uygulanan işlemler eski odun örnekleri teşhisinde kullanılan tek bir standardın/prosedürün takip edilmesi şeklinde gerçekleşmemiş, literatür bilgilerine dayalı olarak konu ile ilgili farklı kombinasyonların denenmesi şeklinde gerçekleşmiştir. Bu denemeler sonrasında, şu işlemler çalışmada uygulanmıştır; örnek bir cam laboratuvar tüpü içerisine yerleştirilerek üzerine kaynamış saf su ilave edildi. Örneğin su içerisine batması plastik bir çubuk ile sağlandı. Örnek bu durumda laboratuvar odası sıcaklık şartlarında 3 gün su içerisine bekletildi. Daha sonra \%70 lik etanol ve gliserol karışımı içerisinde (1/3) bir gün bekletildi. 2010 yllında uygulanan bu işlemlere çok benzer bir prosedürün, daha sonra başka araştırmacılar tarafından da kullanıldığı görülmüş olup, işlemdeki temel fark gliserol/etanol oranı (1/4) dır (Timar vd, 2012). Örnek disposable olarak ifade edilen mikrotom bıçağı ile gerekli görülen kısımlardan tıraşlanıp düzeltilerek, mümkün olduğu kadar düzgün kesitler alınabilecek şekil verildi. Bu işlemden sonra parafine gömme işlemi yapıldı. Kızaklı mikrotomda kalınlı̆̆ $15-20 \mu$ civarında kesitler alındı. Boyama işleminde safranin kullanılmış, yıkama işlemi ise filtre kâğıdı üzerine yerleştirilen örneklerin bir pipet yardımıyla sırasıyla saf su ve alkol ile (\%70 ve \%90) yıkanması, en son aşamada yalnızca kalıcı preparat için ksilen uygulaması şeklinde gerçekleştirilmiştir. Örnek kesite mümkün olduğunca az temas edilmesine önem verilmiş, anatomik incelemelerde çok kullanılan metal tutucuların kullanımı en az seviyede tutulmuş ve piyasadan temin edilen silikon uçlu bir tutma aparatı kullanılmıştır. Entellan kullanılarak her sütun için tek bir kalıcı preparat hazırlanmış, diğerleri ise geçici preparatlar olarak hazırlanarak Olympus CX 41 mikroskobunda incelenmiş ve bu mikroskoba bağlı görüntüleme sistemi ile görüntülenmiştir.

Mikroskopta inceleme işleminde 4x objektiften başlanarak 10x, 20x ve özellikle torusların incelenmesinde 40x objektifler kullanılmıştır. Görüntüler alınırken ise 4x,10x objektifler ile genel görüntüler alınmış, bazı detay görüntüleri için 20x objektif kullanılırken, bazı görüntülerin düzenlenmesi ve detay pencerelerdeki görüntüler için Image $\mathbf{J}$ programında istenilen görüntü alınıncaya kadar büyütme yapılmıştır. Bu programda elde edilecek görüntüler nümerik ölçümlerde kullanılmayacağı için büyütme oranına değil görüntüde yakalanmak istenen özelliğe odaklanılmıştır. Bu nedenle makale içerisinde objektif bilgisi verilmeyen görüntüler Image J de yapılan bu büyütme veya görüntü işleme işlemlerine ait görüntülerdir.

Tamamlanan başka bir projede (TUBİTAK 110-O-560) ağaçlar dikili haldeyken tahribatsız muayene için örnek alımı amacıyla bazı cihazlar (elektrikli ve şarjlı artım burguları olarak ifade edilebilir) yazar tarafından modifiye edilerek oluşturulmuştur. İsveç’teki Wasa müzesine yapılan ziyarette örnek alımı konusunda elde edilen bilgiler doğrultusunda (Şekil 2a), 2015 yılında yapılan ikinci örnek alımında bu modifiye cihazdan yararlanılmıştır (Şekil $2 b$ ). Bu örneklerden de yukarıda izah edilen şekilde preparatlar hazırlanmış ve mikroskobik görüntüler elde edilmiştir. İncelenen her sütunda üç kesitin hepsine ait görüntü elde edilmesi mümkün olmamıştır. Bu durumda sedirin teşhisinde çok önemli ve ayırt edici olan dişli torus görüntüsünün net olarak görüldüğü bir radyal kesit görüntüsünün elde edilmesi öncelikli tutulmuştur.

Makale yazımında kullanılan terminoloji ve teşhis için IAWA tarafından kullanılan yayın temel alınmış (IAWA Committe 2004) ayrıca Toros sediri ile ilgili bilgi edinilen bazı yayınlardan (atlaslar, temel kaynak kitaplar, makaleler) yararlanılmıştır (Fahn vd., 1986; Hoadley, 1990; Bozkurt ve Erdin, 2000; Merev, 2003; Schoch vd., 2004; Esteban vd., 2004, Yaman, 2007; Hayar vd., 2010; Akkemik ve Yaman, 2012; Yaman, 2019).

Sedir odunu kendine has bir kokuya sahip olup, bu koku özellikle bu tür ile deneyimi olan kişiler tarafindan ayırt edilebilen ve bilimsel olarak da türün ayırt edici özelliği olarak kabul edilen fiziksel bir özelliğidir (Bozkurt ve Erdin, 2000; Merev, 2003). Bu nedenle incelenen sütunlarda koku ile ilgili tespitler de not edilmiştir. 

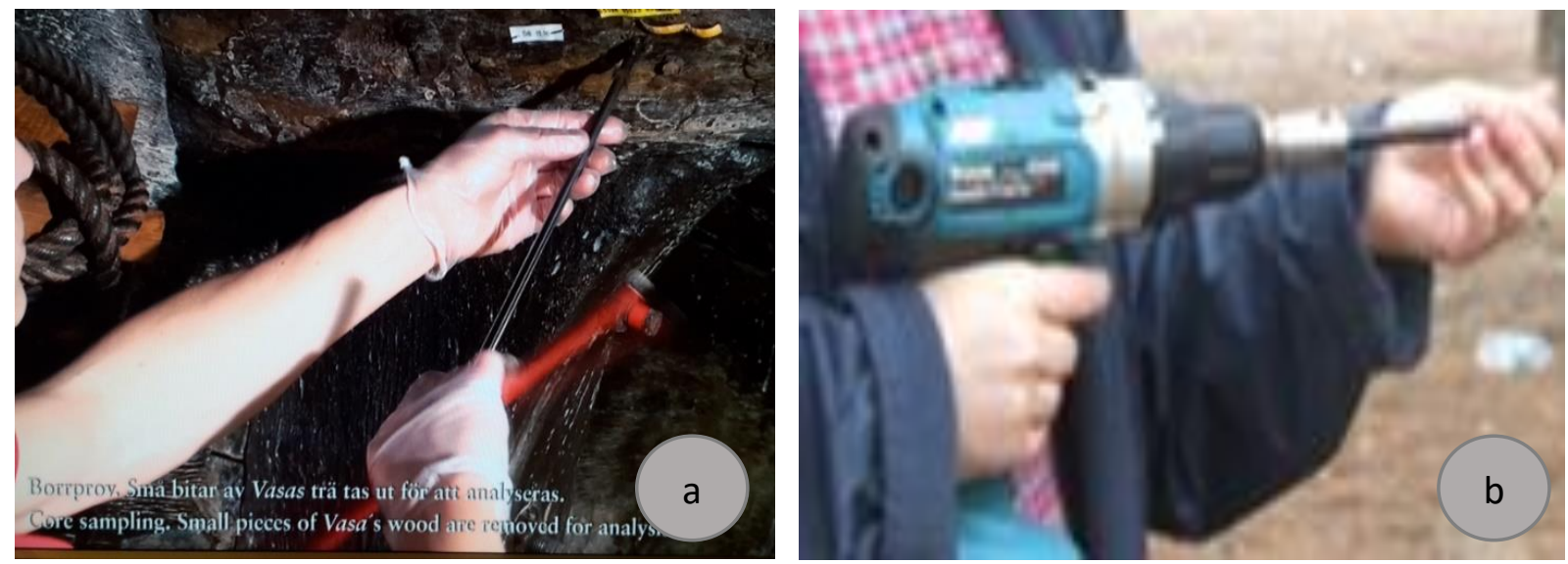

Şekil 2. a:Wasa müzesinde koruma altındaki ahşap gemiden teşhis için odun örneklerinin nasıl alındığına dair gösterim (Foto: Bilgin İÇEL); b: 2015 yılında yapılan örneklemede kullanılan modifiye edilmiş cihaz (Bilgin İÇEL)

\section{Bulgular ve Tartışma}

Örneklerin enine kesitlerine ait iki mikroskobik görüntü aşağıda gösterilmiştir (Şekil 3). Tür tanımlaması için, bir türe özgün olan bazı anatomik özellikler teşhis aşamasında uzmanlara büyük kolaylık sağlamaktadır. Ahşap örneklerinin tür teşhisinin yapılmasına olanak sağlayan ve üzerinde çalışılan anahtar nitelikteki anatomik özellikler incelenen bütün örneklerde aynı karakteristik özelliklerin bulunduğunu göstermiştir. İncelenen sütunlara ait tüm görüntüler çok yer kapladığı için, örnek olarak ilk incelemenin yapıldığı 21 numaralı sütun ve sonraki incelemede incelenen örneklerden rasgele seçilen bir sütuna (15 numaralı sütun) ait kesit görüntüleri burada verilmiştir (Şekil 4). Örneklerde yıllık halka sınırları belirgindir. İlkbahar odunu traheidleri ince çeperligeniş lümenli iken, yaz odunu traheidleri kalın çeperli ve dar lümenlidir. Yaz odunu traheidleri aynı zamanda radyal yönde yassılaşmıştır. İncelenen kesitlerde traumatik reçine kanalına rastlanmamıştır. İncelenen preparatlarda fusiform öz ışınına rastlanmamıştır. Öz ışınları heterojen ve genel olarak tek sıralıdır. Çok nadir olarak birkaç öz ıșınının bir kısmında öz ışınının birkaç paranșim hücresinin ikili sıra oluşturduğuna rastlanmıştır. İncelenen örneklerde ilkbahar odunu traheid-özışını karşılaşma yeri geçitleri genel olarak, cupressoid ve taxodioid tipte görülmüş olup (Şekil 5), piceoid tipe benzer karşılaş̧ma yeri geçidine çok az sayıda rastlanmıştır (Şekil 6, daire içerisindeki görüntü). Kesitlerde yapılan tüm incelemelere bağlı olarak, özellikle tüm örneklerde görülen dişli torus yapısı (Şekil 4' te radyal kesitteki detay pencereleri ve Şekil 6), incelenen ahşap örneklerinin Gymnospermae'lerden Pinaceae familyası, sedir (Cedrus) cinsine ait olduğunu göstermiştir. Eşrefoğlu Camisinin bulunduğu bölge geçmişten günümüze Cedrus libani (Toros sediri) nin doğal yayılış alanında bulunmaktadır (Özkan, 2003; Boydak ve Çalıkoğlu, 2008; Hajar vd., 2010; Ek Şekil 1). Caminin yapıldığı dönem itibariyle ahşap ihtiyacının en yakın doğal kaynaktan temin edilmesi ihtimali, yabancı bir sedir türünün kullanılma ihtimaline göre çok yüksektir. Bu nedenle, incelenen ahşap örneklerinin Cedrus libani A. Rich. (Toros sediri) türüne ait olduğu kanaatine varılmışıtır. Bu makalenin tamamen tür teşhisi odaklı olarak "Giriş" kısmında izah edilen gerekçe ile hazırlanması, dişli torus yapısının ve diğer anatomik gözlemlerin tür teşhisinde literatürdeki bazı yayınlarda (Yaman, 2019) Toros sediri için yeterli görülmüş olması sebebiyle, nümerik ölçümlere bu yayında yer verilmesine gerek görülmemiş̧ir. 


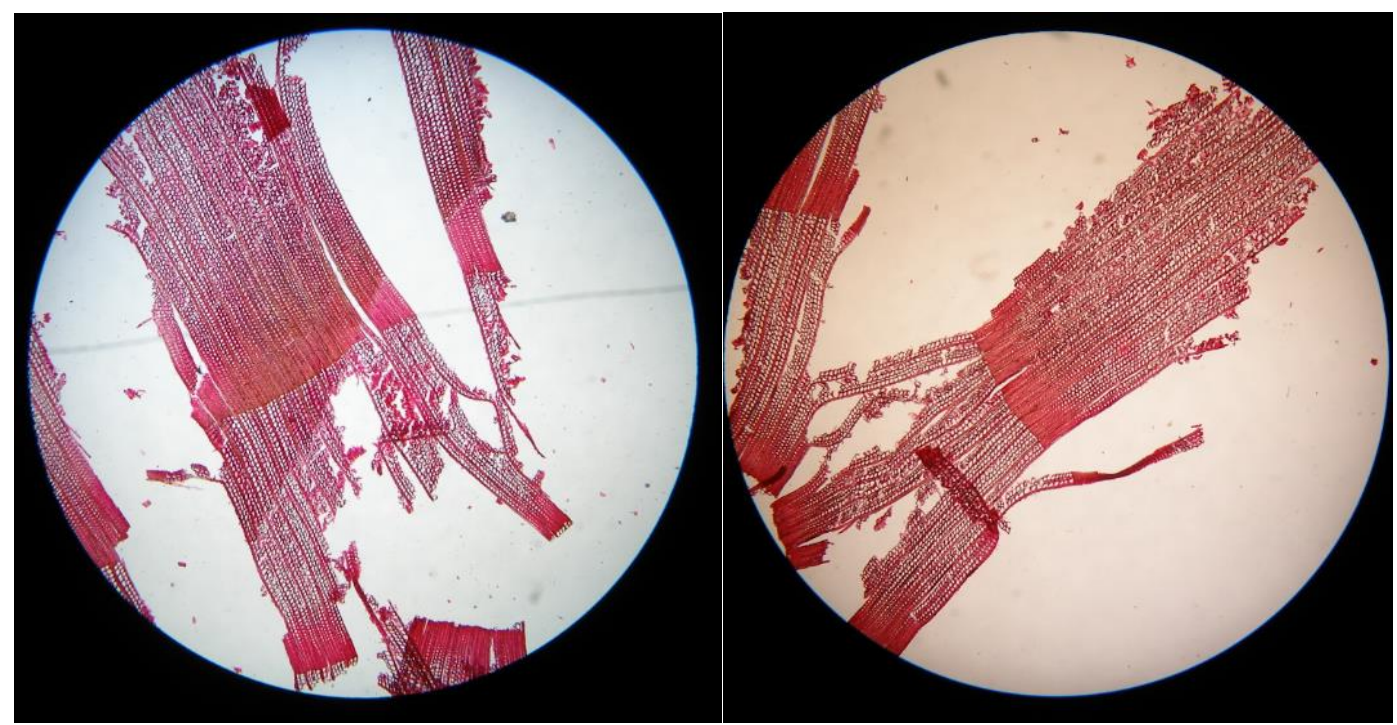

Şekil 3. Enine kesitlere örnek mikroskobik görüntüler (Objektif:4 x)

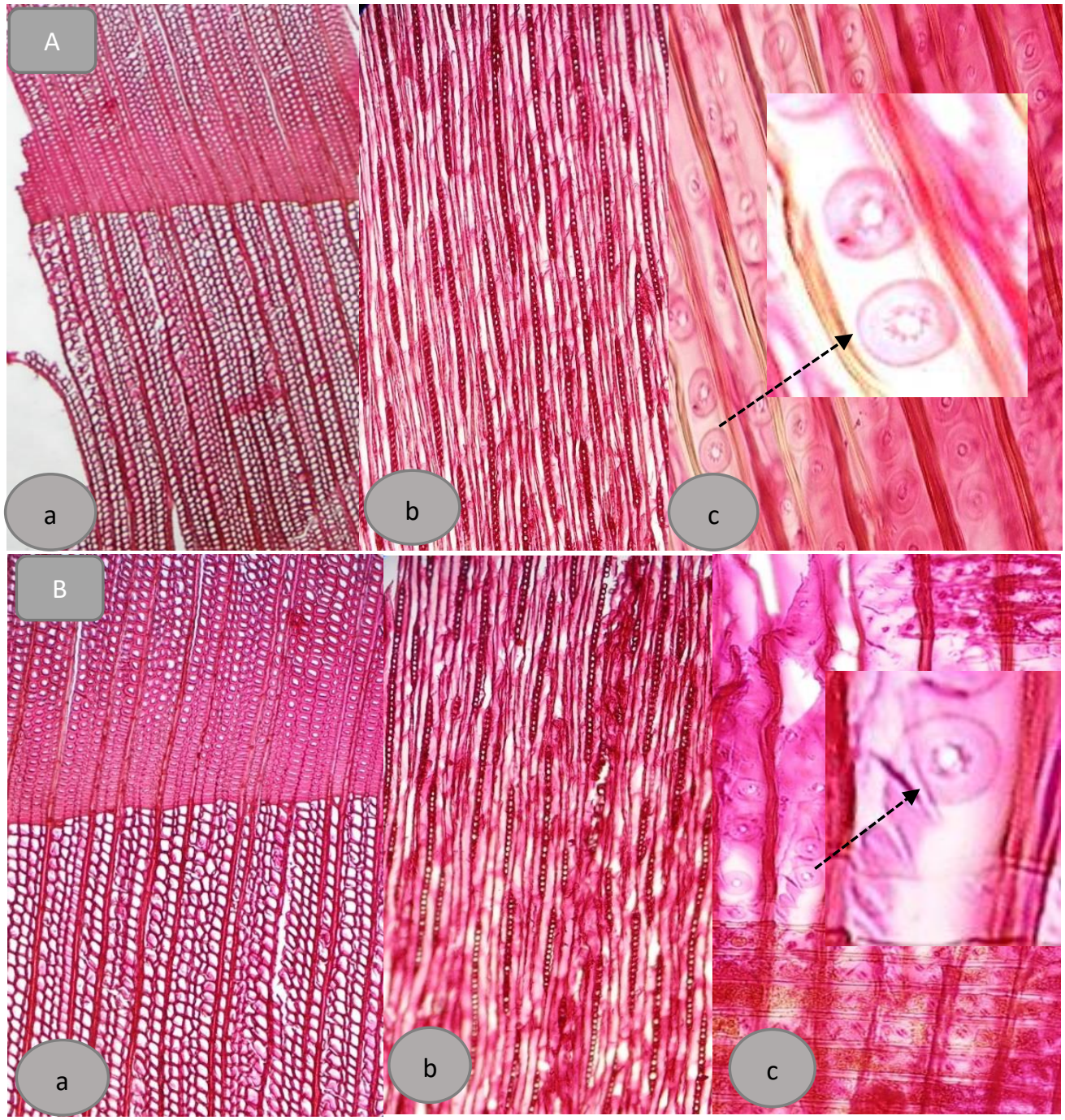

Şekil 4. Mikroskobik (a:enine, b: teğet, c:radyal kesit) görüntüleri (A: 21 numaralı sütun; B: 15 numaralı sütun) 


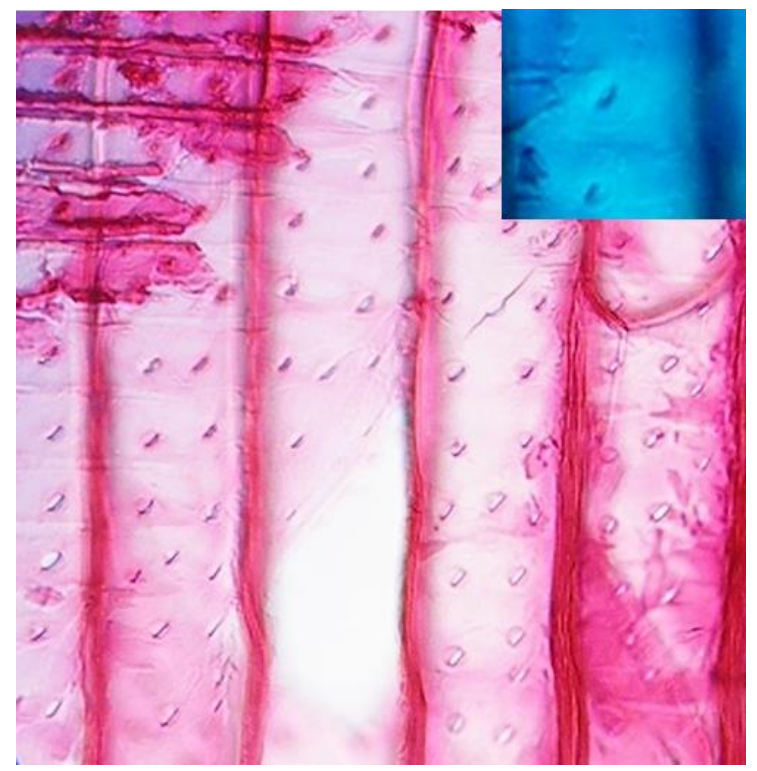

Şekil 5. Genel olarak gözlemlenen cupressoid ve taxodioid tipteki karşılaşma yeri geçitleri. Köş̧edeki detay penceresi rastlanan cupressoid tipteki geçitleri göstermek için Image J programında renk maviye çevrilerek ve büyütme işlemi yapılarak verilmiştir.
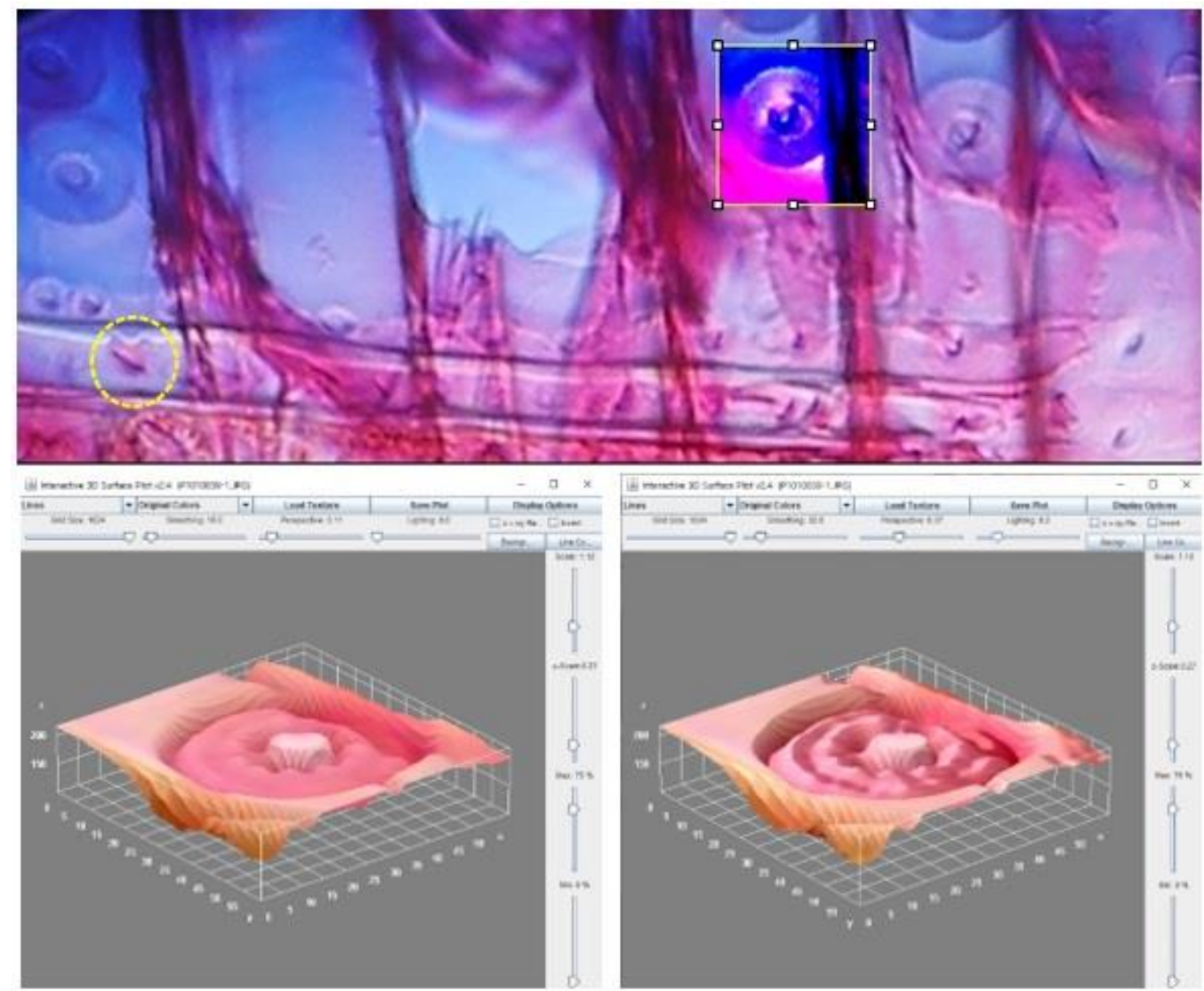

Şekil 6. 2-D ve 3-D dişli torus görüntüleri (Üstteki 2-D görüntüde kare detay penceresinde yer alan torusun dişli görüntüsünün daha net görülmesinin sağlanması amacıyla 3-D görüntüler Image J programı kullanılarak oluşturulmuştur.

Bu çalışmada, gözlemlenen anatomik özellikler ve özellikle dişli torus yapısı dikkate alınarak, ağaç türü Cedrus libani A. Rich. (Toros sediri) olarak teşhis edilmiştir. Ayrıca koku incelemesi notları da dikkate alınmışıtır. Fakat koku özelliği eski ve üst yüzey işlemi görmüş odun örneklerinde taze haldeki sedir odunu kadar ayırt edici bir 
özellik olarak ortaya çıkmamaktadır. Nitekim 2010 yılında 21 numaralı sütundan kopmak üzere olan parçalardan elde edilen küçük odun örneklerinde belirgin sedir kokusu alınmamıştır. 2015 yılında yapılan örneklemede ise 2 sütunda hafif, 4 sütunda ise biraz daha belirgin şekilde yazar tarafından tanımlanan koku örnek alımı sırasında not edilmiştir. 2015 yılında kullanılan cihazın çalışma prensibi itibariyle belirli bir derinliğe doğru örnek alımı gerçekleştirmesi sebebiyle bu kokunun alınabildiği düşünülmektedir. Koku özelliği çalışmada temel bir teşhis kriteri olarak değerlendirilmemiştir.

Cami ile ilgili bir kaynakta (Efe, 2012), üç ahşap sütunun daha sonraki bir tarihte ilave edildiği bilgisine ulaşılmaktadır. Cami içerisindeki ahşap sütunlarda şekilsel farklılıklar mevcuttur. Ana ibadet kısmındaki 42 sütundan 22 tanesi sekizgen, 1 tanesi ongen, 19 tanesi yuvarlak gövde şekline sahiptir. Yapılan bakımlarda sütunlara bazı üst yüzey işlemi (gomalak uygulaması) uygulandığı, bir tanesine ise işlem uygulanmadan bırakıldığı görülmüştür. Sütunlar üzerinde ayrıca farklı şekil, çizgiler vb. görsel farklılıklar bulunmaktadır (Şekil 7). Ayrıca camide ağaç türünün farklı olma olasılığı olduğu düşünülen bir sütundan da örnek alımı denenmiştir. Mikroskobik teşhis için yeterli boyutta örnek elde edilemediği ve örnek alım işlemi sırasında alınan örnek çok küçük parçalar halinde parçalandığı için, bu küçük örneklerde SEM incelemesi gerçekleştirilmiştir. Bu incelemede bazı kenarlı geçitlerin görüntüsü yakalanabilmiştir (Şekil 8). SEM de incelenen bu örnekte toruslarda özel bir oluşuma rastlanmamış olması, camideki tüm sütunların sedir olmayabileceği ihtimalinin de olduğunu düşündürmektedir.
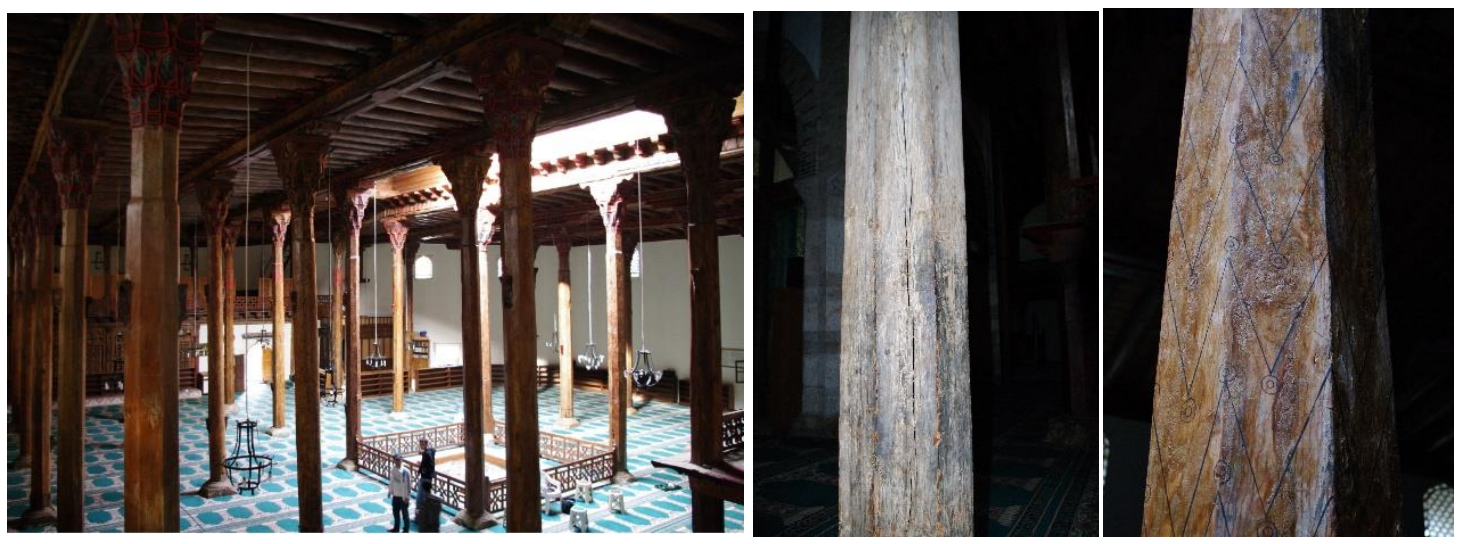

Şekil 7. Cami içerisindeki ahşap sütunlara ait görüntüler (Foto: Bilgin IÇEL)

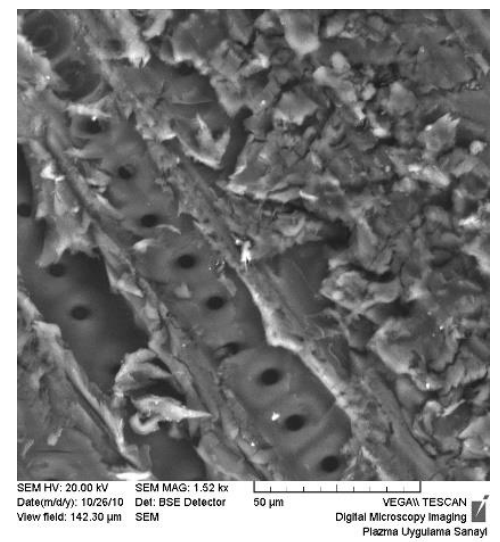

Şekil 8. Bazı sütunların farklı ağaç türü olabileceği ihtimalini düşündüren SEM görüntüsü

\section{Sonuç ve Öneriler}

$\mathrm{Bu}$ çalışma sonuçlarına göre, Eşrefoğlu Camisinde incelenen 7 adet ahşap sütunun ağaç türünün Toros sediri olduğu söylenebilir. Bu sayı camideki inceleme alanı olarak seçilen ana kısımdaki ahşap sütun sayısının 1/6 sıdır. İncelenen örnek oranı ve makalede açıklanan gerekçelerle birlikte göz önüne alındığında, camideki tüm sütunların sedir olduğu yönünde bir genelleme yapmak şu anda mümkün değildir. Bu durumun dikkate alınması ve yapı ile 
ilgili yapılacak yayın ve haberlerde ağaç türü ile ilgili genelleme yapılmaması gerekmektedir. Bilimsel bulgulara dayalı olarak tür teşhisi yapılan sütunların numaraları makale içerisinde verilmiştir. Kuşku duyulan bazı sütunlarla ilgili olarak, neden bu kuşkunun oluştuğuna dair bilgiler paylaşılmış fakat, sütun numaraları dile getirilmemiştir. Bunun sebebi; eldeki bilimsel verilerin çok kısıtlı olması ve bazı kuşkuların kişisel gözlemlere ve çok sınırlı veriye dayanması olarak ifade edilebilir. İleride konu ile ilgili olarak başka araştırmacılar tarafından yapılabilecek çalışmalarda, bu kişilerin bağımsız gözlem ve kanaatlerine etki etmemesi amacıyla kuşku duyulan sütunların hangileri olduğu ifade edilmemiştir. Gelecekte yapılabilecek çalışmalar için en önemli öneri; bu yapıda örnek alımı konusunda ortaya konulan kısıtlar nedeniyle, maddi ve teknik imkanlar sağlanabilirse mikrotomografik, mikro radyografik, yakın kızılötesi inceleme vb. gelişmiş tekniklerle çalışılması olabilir.

\section{Teşekkür}

Bu çalışmanın verilerinin elde edilmesi sırasında yardım ve destekleri olan Vakıflar Genel Müdürlüğü, Konya İl Müdürlüğü yetkililerine, Eşrefoğlu Camisinde uzun yıllar imam-hatiplik görevini yürütmüş olan ve çalışmalarım süresince yardımlarını gördüğüm, yapıyı koruma konusundaki hassasiyeti ile özellikle takdir ve teşekkür edilmesi gereken İsmail Efe'ye, laboratuvar çalışmalarının bazı kısımlarının yürütüldüğü uzun bir dönem görev yaptığım Süleyman Demirel Üniversitesi Orman Fakültesi yetkililerine, çalışmanın diğer kısımlarının yürütüldüğü Çanakkale Onsekiz Mart Üniversitesi ilgili birimlerine, bu çalışmanın ortaya çıkmasındaki katkıları için teşekkür ederim. Ek Şekilldeki harita çizimi Dr.Öğr.Üyesi Akın Kıraç tarafından Akdeniz Bölgesinde kendi tespit ettiği meşcere koordinatlarına göre yapılmıştır. Şekilsel düzenlemelerde Alperen Güller'in yardımı olmuştur. Kendilerine teşekkür ederim.

\section{Kaynaklar}

1. Akkanat C., (2009). Ahşabın secdeye daveti: Beyşehir Eşrefoğlu Camii, Diyanet Aylık Dergisi, Say1:221, sayfa:54-57.

2. Çetinaslan M., (2013). Hünkâr Mahfillerinin Ortaya Çıkışı, Gelişimi ve Osmanlı Dönemi Örnekleri, Selçuk Üniversitesi Sosyal Bilimler Enstitüsü Dergisi, 29:61-74.

3. Doh C.H., (2000). ICOMOS Charter of International Wood Committee; principles for the preservation of historic timber structures, Preservation Science Journal, 9(1):53-55.

4. Doğu D., (2001). Odun teşhisinin genel özellikleri, Doğu Akdeniz Ormancılık Araştırma Müdürlüğü DOA Dergisi, 7:83-96.

5. Erakan A., (2010). Tarihi ahşap sütunlu camilerin sonlu elemanlar analizi ile taşıyıcı sistem performansının Belirlenmesi, SDU International Journal of Technologic Sciences, Vol. 2, No 1:41-54.

6. Esteban L.G., de Palacios P.d.P., Casasus A.G., Fernandez F.G., (2004). Characterisation of the xylem of 352 conifers, Forest Systems, 13(3): 452-478.

7. Hajar L., Francois L., Khater C., Jomaa I., Deque M., Cheddadi R., (2010). Cedrus libani (A. Rich) distribution in Lebanon: Past, present and future, Comptes Rendus Biologies, 333:622-630.

8. Hwang K., Park B.-S., Park J.-H., Chong S.-H. (n.d.), (2009). Identification of Wood Used for Column Members of Historic Korean Timber Structures, Journal of Asian Architecture and Building Engineering, $8(2), 525-529$.

9. IAWA Committee (2004). IAWA list of microscopic features for softwood identification by an IAWA Committee. (Eds. Richter, H.G., Grosser, D., Heinz, I. \& Gasson, P.E.) IAWA Journal, 25, pp.1-70.

10. Koçu N., (2014). Tarihi Beyşehir Eşrefoğlu Camii'nde Geleneksel Yapı Malzemeleri ve Onarım Çalışmalarının Değerlendirilmesi, Artium, Cilt 2, Sayı 1, 58-69 ISSN : 2147-6683.

11. Kweonhwan H., Beyung-Su P., Jung-Hwan P., Song-Ho C., (2009) Identification of Wood Used for Column Members of Historic Korean Timber Structures, Journal of Asian Architecture and Building Engineering, 8 (2): 525-529, DOI: 10.3130/jaabe.8.525.

12. Macchioni N., Bernabei M., (2018). Identifying the Wood of Historic Artefacts: Basic Information or Simply a Curiosity? Glob J Arch \& Anthropol, 6(1): GJAA.MS.ID.555677.

13. Önge Y., (1975). Selçuklularda ve Beyliklerde Ahşap Tavanlar, Vakıflar Dergisi, Sayı VII, Ankara.

14. Timar M.C., Gurau L., Porojan M., (2012). Wood species identification, a challenge of scientific conservation, International Journal of Conservation Science, Volume 3, Issue 1, January-March: 11-22.

15. Uysal Z., (2014). 18. Yüzyıldan Ahşap Direkli İki Cami, Turkish Studies - International Periodical For The Languages, Literature and History of Turkish or Turkic, Volume 9/10 Fall 2014, p. 1107-1123.

16. Yaman B., (2007). Anatomy of Lebanon cedar (Cedrus libani A. Rich.) wood with indented growth rings, Acta Biologica Cracovensia-Series Botanica, 49(1): 19-23. 
17. Yaman B., (2019). Akseki Sarıhacılar köyü cami ahşap teşhisi, Bartın University International Journal of Natural and Applied Sciences, 2 (1): 44-49.

18. Brancaccio F., (2016). 18. Yüzyıla Ait Güney İtalya Mimarisinde Kerestenin Geleneksel Kullanımı: Çatı Yapılarının Restorasyonu/ Traditional Use of Timber in XVIII Century South Italian Architectures Restoration of Roof Structures, Symposium on restoration and conservation of traditional timber structures 4, 26-27 Nisan 2016, İstanbul.

19. Yeğin M., (2008). Geleneksel yapıların restorasyonunda malzeme, teknoloji ve tekniklerin araştırılması geliştirilmesi, Üniversite-Sanayi Işsbirliği Merkezleri Platformu (USİMP) Üniversite Sanayi İşbirliği Ulusal Kongresi, 26 - 27 Haziran 2008, Adana.

20. Çavuș E., (2018). Selçuklu dönemi çini mozaik bezemelerinin seramik formlar üzerine aktarımı Eşrefoğlu Seyfettin Süleyman Bey Külliyesi, Yüksek Lisans Tezi, Süleyman Demirel Üniversitesi Güzel Sanatlar Enstitüsü (http://tez.sdu.edu.tr/Tezler/TS02846.pdf).

21. Özkan,K., (2003). Beyşehir Gölü Havzasının Yetişme Ortamı Özellikleri ve Sınıflandırılması, Doktora tezi, İ.Ü. Fen Bilimleri Ens. Orman Mühendisliği Anabilim Dalı, İstanbul.

22. Akkemik Ü., Yaman B., (2012). Wood Anatomy of Eastern Mediterranean Species, 310 pp., illus., Kessel Publishing House, ISBN 978-3-941300-59-0.

23. Boydak M., Çalıkoğlu M., (2008). Toros Sedirinin Biyolojisi ve Silvi Kültürü, OGEM-VAKFI Yayınları, Ankara.

24. Bozkurt Y., Erdin N., (2000). Odun Anatomisi, İstanbul Üniversitesi orman Fakültesi,346 s., ISBN:975404-592-5.

25. Efe İ., (2012). Eşrefoğlu Camii ve Külliyesi Beyşehir Dokuz Yayınları, ISBN:9786054737000.

26. Fahn A., Werker E. \& Baas P. (1986). Wood anatomy and identification of trees and shrubs from Israel and adjacent regions Jerusalem. Israel Academy of Sciences and Humanities, 221p.

27. Hoadley R.B., (1990). Identifying wood: accurate results with simple tools. Taunton Press, Newtown, Connecticut. ISBN 0-942391-04-7.

28. Merev N., (2003). Odun Anatomisi ve Odun Tanıtımı, KTÜ Orman Fakültesi Yayın No. 210, Fakülte Yayın No. 32, Trabzon.

29. UNI 11118 (Cultural Heritage - Wooden Artefacts ; Criteria for the identification of wooden species).

30. URL1:UNESCO:http://www.unesco.org.tr/Pages/125/122/UNESCO-D\%C3\%BCnya-Miras\%C4\%B1Listesi (17.06.2020).

31. URL2: https://islamansiklopedisi.org.tr/esrefoglu-camii (10.06.2020).

32. URL3: http://www.haberkonya.com/esrefoglu-cami-hakkinda-genel-bilgi-21618h.htm (Son erişim Tarihi: 12.06.2020)

33. Croatto G., Turrini U., (2014). Restoration of historical timber structures - Criteria, innovative solutions and case studies, Restoration of historical timber structures P.B. Lourenço, J.M. Branco e H.S. Sousa (eds.) (http://www.hms.civil.uminho.pt/events/intervir_madeira/119_136.pdf) (05.05.2020).

34. Zvyagintseva V., (2017). Ahşap Restorasyonu, Marmara Üniversitesi Fen Edebiyat Fakültesi, Sanat Tarihi (https://www.academia.edu/33210838/Ah\%C5\%9Fap_Restorasyonu) (17.06.2020).

35. Schoch W., Heller I., Schweingruber F.H., Kienast F., (2004). Wood anatomy of central European species. (www.woodanatomy.ch) (05.05.2020). 


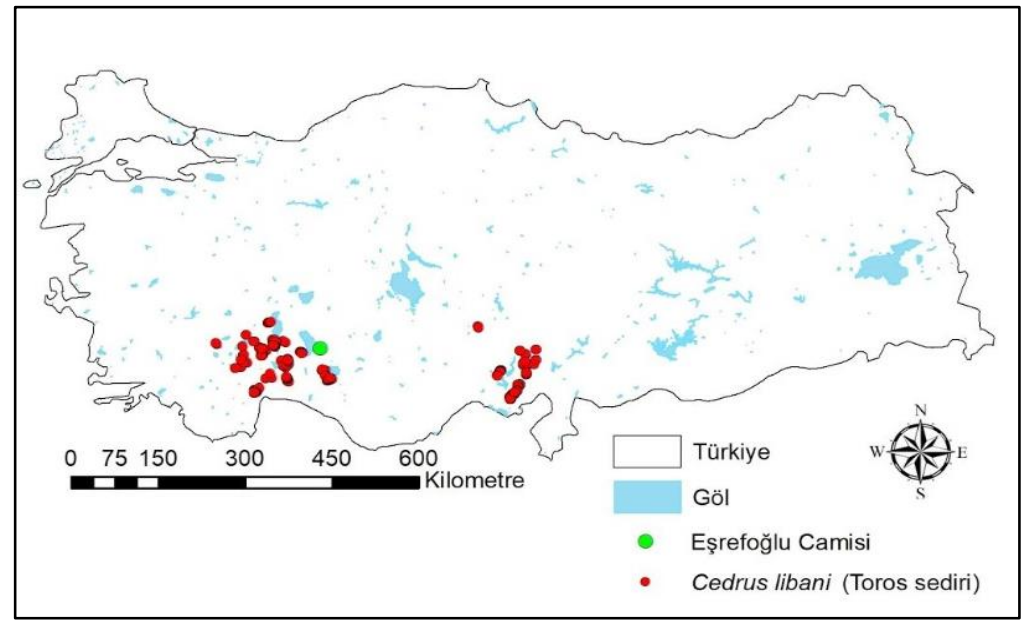

Ek Şekil 1. Türkiye haritası üzerinde Eşrefoğlu Camisi ve Toros sedirinin Akdeniz Bölgesindeki doğal yayılışı (Çizim: Akın KIRAÇ). 